\title{
MORPHOMETRIC RELATIONSHIPS, GAMETOGENIC DEVELOPMENT AND SPAWNING OF THE GEODUCK CLAM PANOPEA GLOBOSA (BIVALVIA: HIATELLIDAE) IN THE CENTRAL GULF OF CALIFORNIA
}

\author{
EUGENIO ALBERTO ARAGÓN-NORIEGA, '" JORGE CHÁVEZ-VILLALBA,' \\ PAUL E. GRIBBEN, ${ }^{2}$ EDGAR ALCANTARA-RAZO, ${ }^{\prime}$ ALFONSO N. MAEDA-MARTINEZ, ${ }^{3}$ \\ EDNA MARÍA ARAMBULA-PUJOL, 'ALMA ROSA GARCIA-JUAREZ ${ }^{1,4}$ AND \\ ROSALIO MALDONADO-AMPARO \\ 'Centro de Investigaciones Biológicas del Noroeste. Unidad Sonora. Km 2.35 Camino al Tular, Estero \\ Bacochibampo, Guaymas, Sonora 85454, México: '2 Department of Environmental Science, University' \\ of Technology, Sydney, P.O. Box 123. Broadway NSW 2007. Australia: ${ }^{3}$ Centro de Investigaciones \\ Biológicas del Noroeste. Mar Bermejo 195, Playa Palo de Santa Rita. La Paz, B.C.S. 23090. México: \\ ${ }^{4}$ Centro Regional de Investigaciones Pesqueras. Calle 20605 sur. Col. La Cantera, Guaymas, Sonora \\ 85400. México: ${ }^{5}$ Centro de Estudios Tecnologicos del Mar No.3. A. P. 742, Guaymas, Sonora 85480. \\ México
}

\begin{abstract}
This paper describes morphometric relationships, and the timing of gametogenic development and spawning for the geoduck clam Panopea globosa (Dall 1898) from a population in the east central Gulf of California. Clams were collected monthly for a year (October 2004 to October 2005). and were measured and weighed to obtain morphometric relationships. Standard histological analysis and measurements of oocyte diameters were used to describe the timing of gametogenic development and spawning. Most morphometric variables were significantly correlated. however the coefficients of determination were generally low $(<0.5)$ indicating high variation in measured traits. Early gametogenic development was observed in late summer autumn when SST was high $\left(-30^{\circ} \mathrm{C}\right)$. Development increased as water temperatures fell with ripe individuals observed in early winter $\left(\sim 20^{\circ} \mathrm{C}\right)$. Spawning oceurred between January and February (winter), when SST were at their coolest $\left(\sim 18^{\circ} \mathrm{C}\right)$. Cytological characteristics of the gonad and averages of oocyte diameters for the different reproductive phases were similar to other geoduck species previously described. Overall sex ratios were equal. This study is the first ecological study to be conducted for $P$. globosa. Given the development of fisheries for $P$. globosa and the interest in developing aquaculture for this species, the data provide valuable information for fisheries managers and aquaculturalists and represent the basis for further research on this species.
\end{abstract}

KEY WORDS: Panoped glohosa, geoduck, clam, reproduction, oocyte size. Gulf of California, sex ratios

\section{INTRODUCTION}

Geoduck clams are one of the largest burying clams in the world. They live buried deep in the sediment (up tol $\mathrm{m}$ ) and have long paired siphons that extend to the sediment surface. The Pacific geoduck. Panopea (formerly Panope) abrupta (Conrad 1849) can obtain a shell length of $210 \mathrm{~mm}$ and a total wet-weight of $3.2 \mathrm{~kg}$ (Goodwin \& Pease 1989). Although smaller than $P$. abrupta, shell lengths up to $127 \mathrm{~mm}$ and whole wet weights of $627 \mathrm{~g}$ have been recorded for the New Zealand geoduck, $P$. zelandica (Gribben \& Creese 2005). Growth is rapid for the first $10 \mathrm{y}$ and minimal thereafter (Gribben \& Creese 2005). Both species are also very long-lived with maximum ages of $168 \mathrm{y}$ and $85 \mathrm{y}$, recorded for $P$. abrupla and $P$. zelandica, respectively. The distribution of both species is influenced by the type of substrate with higher densities found in fine sand to fine silty sand bottoms (Campbell et al. 1998. Gribben et al. 2004).

Populations of both $P$. abrupta and $P$. zelandica have been shown to spawn from spring to summer (Sloan \& Robinson 1984. Campbell \& Ming 2003, Gribben et al. 2004). The New Zealand geoduck exhibits functional protandric dioecy with all geoducks first maturing males and a significant proportion of individuals changing sex to females as they age (Gribben \& Creese 2003). These results in sex-ratios that are skewed

*Corresponding author. E-mail: aaragon04 a cibnor.mx towards males in the small age/size classes with females dominating the older/larger size classes. Evidence also suggests that functional protandric dioecy also exists for the Pacific geoduck (Vadopalas et al. 2006), although this has largely been dismissed as an explanation for skewed sex ratios in P. abrupta (e.g. Campbell \& Ming 2003).

Commercial harvesting of $P$. abrupta forms the most important clam fishery on the Pacific coast of North America (Campbell et al. 1998) and is worth in excess of \$35 million annually (Harbo 1998, Hoffman et al. 2000). The major fisheries are found in Washington State, British Columbia, and Alaska. A small experimental fishery (ca. 100 t annually) for $P$. zelandica began in 1988 (Breen et al. 1991), although the fishery was closed in the early 1990 s pending its introduction into the quota management system (Breen 1994). However, there is continued interest in developing fisheries and aquaculture for this species (Gribben \& Creese 2005).

More recently, small-scale exploitation of another geoduck species, Panopea globosa (Dall 1898), has begun. Panopea globosa is a subtropical species endemic to the Gulf of California (Hendrickx et al. 2005). Exploitation of this species is a relative new activity on the Mexican coast. Initially, national fisheries reports included landings of $P$. globosa in a general category together with other clam species (Arambula-Pujol 2006). However, once it became a distinct fishery, landings of this species were recorded separately. Production estimates for the years 
2000. 2001. and 2002 were 8.5 tons. 51 tons. and 35 tons. respectively. Currently, there are only four cooperatives with licenses for the prospective exploitation of P. globosa in the region. However. the commercial potential of the species is becoming increasingly attractive to the fishing industry through both natural harvesting and aquaculture. However, apart from documentation of the presence of $P$. globosa in San Felipe in the Gulf of California $\left(31^{\circ} \mathrm{N}, 115^{\circ} \mathrm{W}\right)$ (Keen 1971) and recent descriptions of large beds to the south in the central Gulf of California near Guaymas, Sonora (Arambula-Pujol 2006), there is no ecological and biological information available from this species.

Developing sustainable fisheries is reliant on obtaining accurate estimates of harvestable biomass. A first step in providing this information is determining morphometric relationships (e.g., shell length versus whole weight relationships) for individuals within a population (Newell \& Hidu 1982). Furthermore. comparison of morphometric relationships among populations can also be used to assess whether stocks have to be managed individually or collectively, and investigate how populations adapt to environmental change (c.g.. Eager et al. 1984, Cerrato \& Keith 1992). Sustainable management of harvested populations also requires determining the regeneration capabilities of natural stocks. Initially this is reliant on a thorough understanding of the reproductive biology and lifehistory of the species to be harvested (Baron 1992). Not only do we need detailed knowledge of the timing of gametogenic development and spawning. but also sex-ratios across a broad range of size classes. Skewed sex-ratios could lead to fisheries inadvertently targeting a single sex resulting in fisheries that are not sustainable (Gribben \& Creese 2003). Initially, successful aquaculture is also reliant to the timing of gametogenic development and spawning events so potential broodstock can be collected at the appropriate time.

The aims of this study are to (1) determine the relationships between key morphometric variables; (2) investigate the timing of gametogenic development and spawning. and (3) determine sex ratios across a range of size classes for $P$. globosa in a population located in the central part of the Gulf of California.

\section{MATERIALS AND METHODS}

\section{Study Site and Organism}

The morphology and reproductive cycle of the geoduck clam. Panopea globosa, was investigated using geoducks collected from Bahia de Guaymas-Empalme $\left(\sim 27^{\circ} 53^{\prime} \mathrm{N}\right.$, $110^{\circ} 43^{\prime} \mathrm{W}$ ) (Fig. 1). Monthly samples of approximately 10 clams (size range $68-239 \mathrm{~mm}$ shell length) were collected subtidally between at $8-12 \mathrm{~m}$ depth using SCUBA from October 2004 through October 2005. However. no samples were collected from June through September 2005 because high levels of suspended material in the bay made it impossible to locate geoduck siphon holes. Once extracted from the sediment. the clams were transported to the laboratory in coolers, and placed in a tank with running seawater.

For each individual, we initially measured three shell variables (shell length, shell width, and body thickness) using vernier calipers (see Fig. 2). After this we measured total wet mass. tissue wet mass. and shell weight by separating the shell from the tissue and blotting both dry to remove excess water. All weight measurements were determined to the nearest $0.1 \mathrm{~g}$ using an electronic balance. Morphometric relationships between all six variables were investigated using correlation analyses for all geoducks collected ( $n=77$ in total).

Gametogenic development and sex ratios were determined using analysis of histologically prepared slides. Histological procedures followed methods used in previous studies (Maldonado-Amparo \& Ibarra 2002a, Maldonado-Amparo \& Ibarra 2002b). Once whole tissue weight was determined for each individual above the gonad and associated viscera were removed. a portion of the tissue was taken from a standard position in the middle area of the gonad and fixed in Davison's Solution for at least $24 \mathrm{~h}$. Samples were dehydrated in a series of ethanol treatments of increasing concentration. cleared in xylene. and embedded in Paraplast at $56^{\circ} \mathrm{C}$ and sectioned at $5 \mu \mathrm{m}$. All sections were stained with hematoxylin and eosin solution and individually mounted on glass slides. The slides

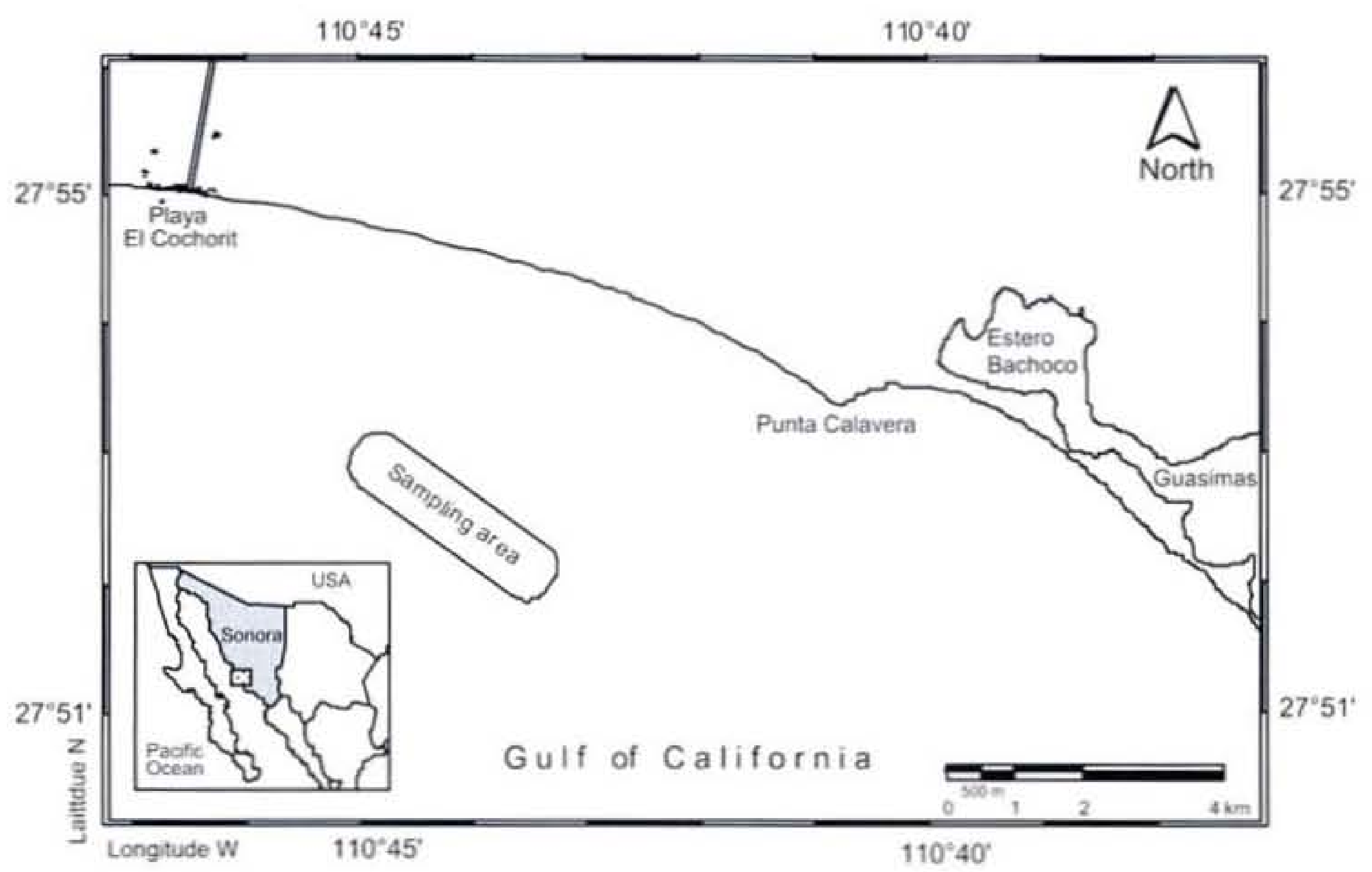

Figure 1. Collection site of Panopea globosa in Bahia de Guaymas-Empalme in the east central Gulf of California. 

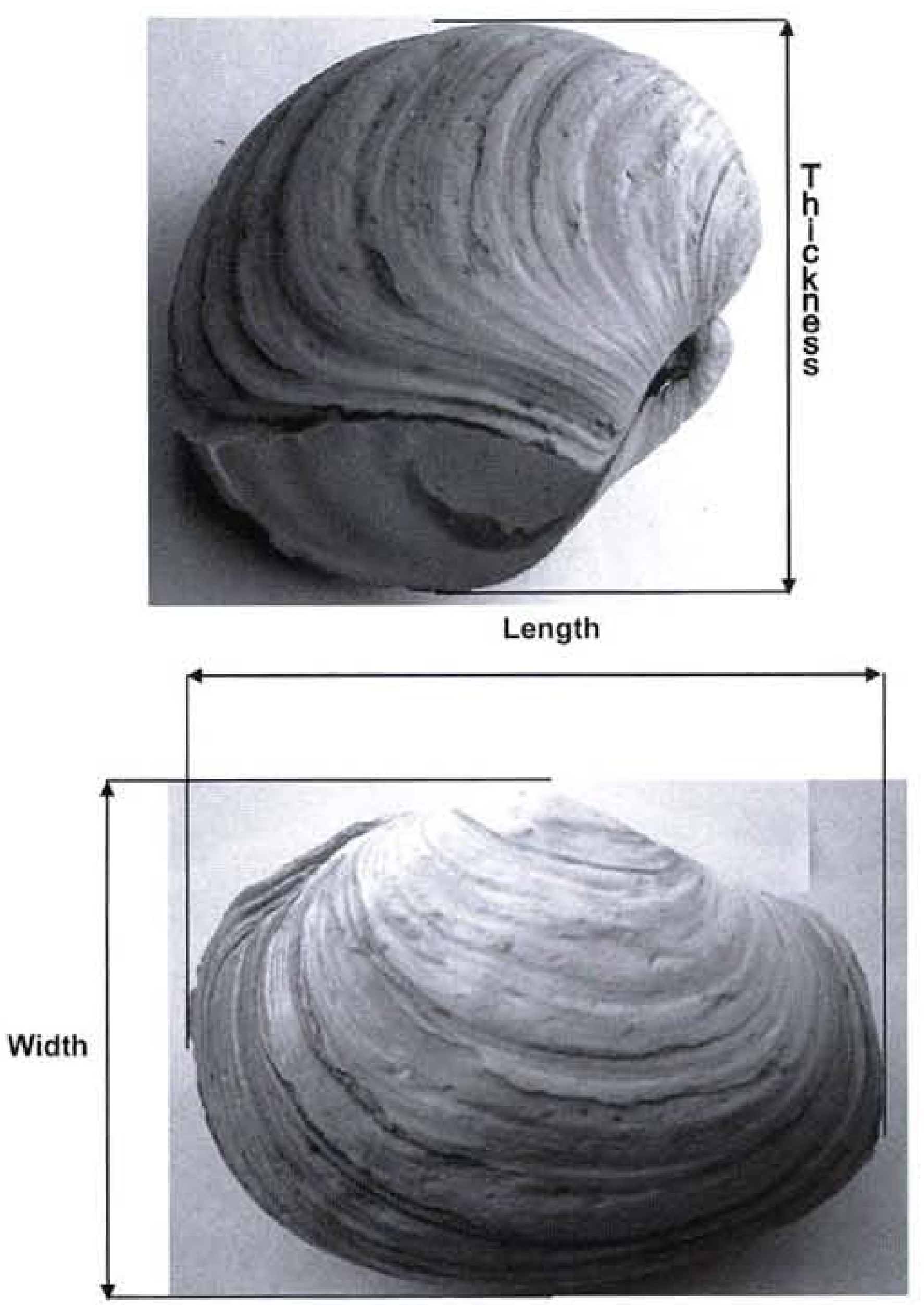

Figure 2. Shell measurements of Panopea globosa from the east central Gulf of California.

were examined under an optical microscope at $4 \times, 10 \times$ and $40 \times$ magnification. Gonads from both male and female clams were placed into five qualitative categories based on those described for $P$. zelandica and $P$. abrupta (see Campbell \& Ming 2003, Gribben et al. 2004 for details): early active. late active, ripe, partially spawned, and spent/resorbing. The gonadal state of each clam was described as one of the five stages based on the most dominant stage present in 10 haphazardly selected follicles from each sample.

The timing of gametogenic development and spawning in geoduck species (as with many other bivalves) (Sloan \& Robinson 1984, Gribben et al. 2004) is correlated with changes in water temperatures. We also investigated whether gametogenic development and spawning in $P$. globosa was correlated to patterns in sea-surface temperatures (SST). Monthly SSTs covering the duration of the study were obtained from the Comprehensive Oceanic and Atmospheric Data Set (COADS) (data provided by NOAA-CIRES Climate Diagnostics Center). The COADS SST fields are computed by optimum interpolation of all in situ and satellite-derived information available. and are commonly distributed as monthly $1^{\circ} \times 1^{\circ}$ grid data (Reynolds et al. (2002). The $28^{\circ} \mathrm{N} .111^{\circ} \mathrm{W}$ data were selected as Central Gulf of California. SSTs and are presented as the monthly average.

For all females collected, monthly mean oocyte diameters $( \pm$ SE) were calculated using procedures described by Rodriguez-
Jaramillo et al. (2001). Sigma Scan ${ }^{\text {TM }}$ image analyzer software was used to measure at least 100 oocytes per female. Measurements followed a standardized procedure to reduce bias when selecting fields for measuring. Transects on gonad preparations were traced in such a way that the longest axis containing oocytes (vertical or horizontal) was always followed to maximize field coverage. All oocytes contained within a field and presenting a well-defined germinal vesicle were measured.

The ratio of males to females was determined from microscopic examination of the histological slides. Clams were deemed sexually mature if gametes were present. Clams were also examined for any evidence of hermaphroditism.

\section{RESULTS}

\section{Morphometric Relationships}

The shell length of all geoducks collected ranged from $68 \mathrm{~mm}$ to $239 \mathrm{~mm}$, shell width ranged from $39-120 \mathrm{~mm}$, shell thickness ranged from $36-136 \mathrm{~mm}$, shell mass ranged from $5.4 \mathrm{~g}$ to $165 \mathrm{~g}$. total mass ranged from $68 \mathrm{~g}$ to $930 \mathrm{~g}$, and total tissue weight ranged from $34 \mathrm{~g}$ to $696 \mathrm{~g}$ (Fig. 3). Mean shell length, thickness and width mass for all geoducks collected were $147(13.5) \mathrm{mm}$. $90.4(5.0) \mathrm{mm}$, and 72.8 (5.1) $\mathrm{mm}$ respectively (Table 1). Overall mean total wet mass, tissue wet mass and shell mass were 533.3 $(43.1) \mathrm{g}, 264.5(20.1) \mathrm{g}$. and 81.4 (3.9) g. respectively. Monthly mean shell length, thickness and width, total wet mass, and tissue wet mass of $P$. globosa did not follow a discernible pattern (Table 1); the largest clams were collected in December 2004 and the smallest in May 2005.

There were significant correlations between all shell traits except for shell thickness versus shell length and shell mass (Fig. 3; Table 2). There were also significant relationships between most shell traits versus total mass and tissue wet mass. except for shell length versus tissue wet mass, and shell thickness versus total wet mass and tissue wet mass. There was also a significant correlation between total wet mass and tissue wet mass. Except for correlations between shell mass versus total wet mass and tissue wet mass, and total wet mass versus tissue wet mass (all $\left.r^{2}>0.50\right)$, the coefficients of determination were generally low $\left(r^{2}<0.30\right)$ indicating high variation in the relationships between traits.

\section{Gametogenic Development and Spawning}

From histological preparations, we confirmed the criteria described by Gribben et al. (2004), who reported 5 reproductive stages: early active, late active. ripe, partially spawned. and spent/reabsorbing (Fig. 4A to J: see Gribben et al. 2004 for detailed descriptions).

Gametogenic development and spawning was synchronous between the sexes so only the overall patterns of gametogenic development are described (Fig. 5A, B). In autumn (October) $2004,50 \%$ of the clams were in the early active stage with the remainder undifferentiated. suggesting that gametogenic development had just begun. Gametes developed quickly and by winter (December) $2004100 \%$ of the clams were ripe. Spawning began in midwinter (January) 2005 when $80 \%$ of clams were partially spent, and the remaining clams completely spawned out. By late winter (February) 2005, nearly all clams were spent $(90 \%)$, and $10 \%$ had resorbed all gametes and were undifferentiated. All clams collected through spring and early summer 

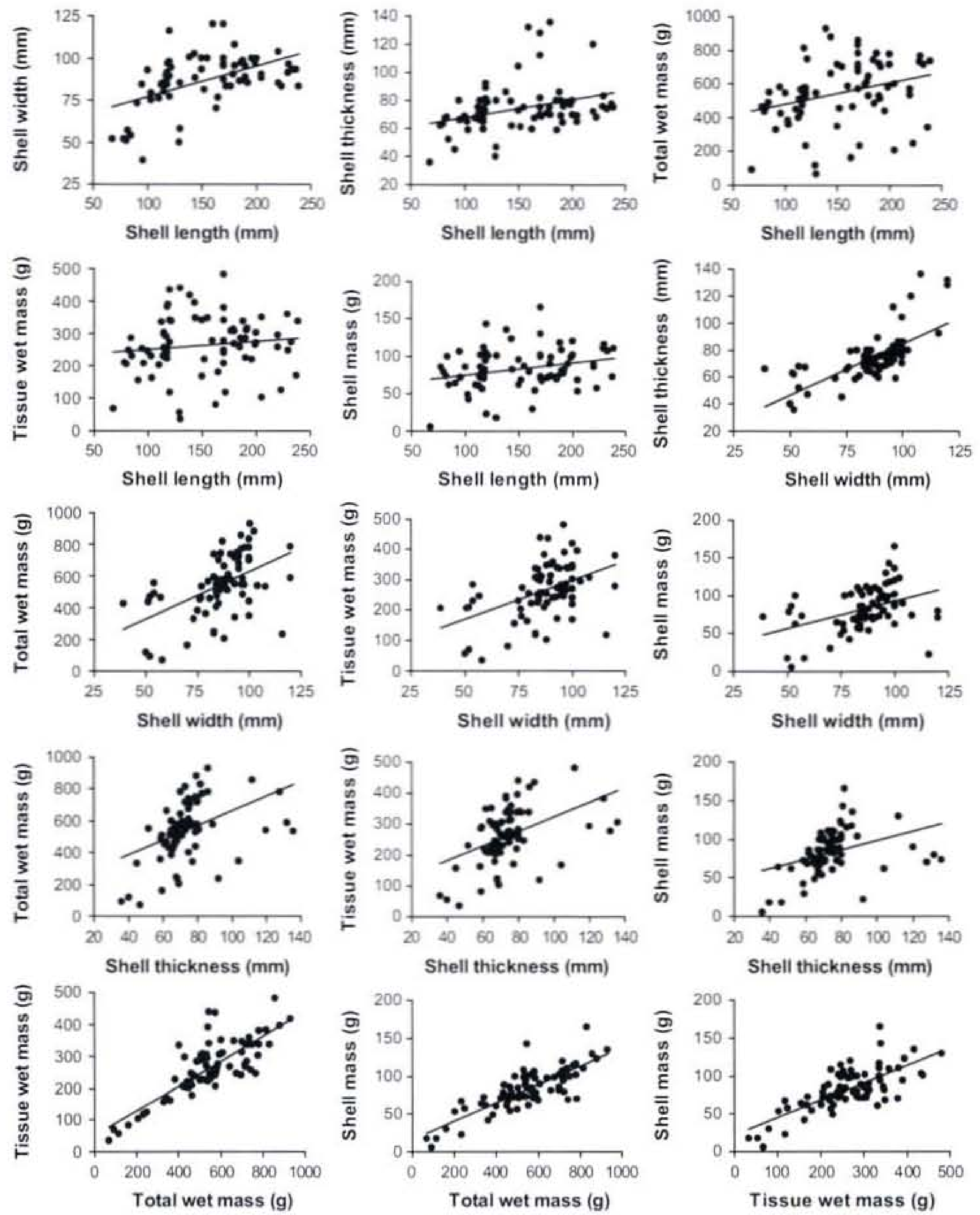

Figure 3. Morphological correlations for Panopea glohosa from the east central Gulf of California.

(March through May) 2005 had resorbed all gametes and could not be sexed. Gametogenic development had begun again by spring (October) 2005 with $95 \%$ of clams in the early active stage. Again development may have started earlier, however we could not collect clams from June to September.

Early gametogenic development was observed in late summer/autumn when SST was high $\left(-30^{\circ} \mathrm{C}\right)$ (Fig. 5). Development increased as water temperature fell with ripe individuals observed in early winter when the SST was $\sim 20^{\circ} \mathrm{C}$. Spawning occurred between January and February (winter), when SST was at its lowest $\left(-18^{\circ} \mathrm{C}\right)$.

\section{Oocyte Diameters}

Oocytes ranged in size from 5-78 $\mu \mathrm{m}$ between October 2004 and January 2005. Mean $( \pm$ SE) oocyte diameters followed patterns observed in the histological stagings (Fig. 6). Smallest mean oocyte diameters occurred in October $2004(8 \pm 1.3 \mu \mathrm{m})$. corresponding to the early active stage. By November, during the late active stage, mean oocyte diameter had risen to $32 \pm$ $11.17 \mu \mathrm{m}$. Ripe oocytes (December) had an average diameter of $46 \pm 8.47 \mu \mathrm{m}$. The largest mean oocyte diameter $(52 \pm 12 \mu \mathrm{m})$ occurred in January. 2005. corresponding to the partiallyspawned and spent stages. Only large unspawned ova remained in the follicles during this period.

\section{Sex Ratio}

Males ranged in shell length from $100.2-239.0 \mathrm{~mm}$, females from $118-237 \mathrm{~mm}$, and unsexed from $68-220$ (Fig. 7). Because of the extended resting stage most clams (42 out of 77 clams collected in total) could not be sexed. However. during gametogenesis all clams $(n=34)$ could be sexed. The overall ratio of males to females was $1: 1(n=17$ in total for both sexes). Because 
TABLE I.

Monthly mean ( \pm SE) morphological measurements for Panopea globosa collected during the study period.

\begin{tabular}{lrcccccc}
\hline \hline \multicolumn{1}{c}{ Date } & $\mathbf{n}$ & $\begin{array}{c}\text { Shell Length } \\
(\mathbf{m m})\end{array}$ & $\begin{array}{c}\text { Shell Thickness } \\
(\mathbf{m m})\end{array}$ & $\begin{array}{c}\text { Shell Width } \\
(\mathbf{m m})\end{array}$ & $\begin{array}{c}\text { Total Mass } \\
\mathbf{( g )}\end{array}$ & $\begin{array}{c}\text { Total Tissue } \\
\mathbf{m a s s}(\mathbf{g})\end{array}$ & $\begin{array}{c}\text { Shell Weight } \\
(\mathrm{g})\end{array}$ \\
\hline Oct 2004 & 8 & $117.9 \pm 5.86$ & $93.9 \pm 6.27$ & $73.6 \pm 3.19$ & $620.0 \pm 73.8$ & $277.9 \pm 33.3$ \\
Nov 2004 & 10 & $175.0 \pm 6.15$ & $96.0 \pm 1.17$ & $72.2 \pm 1.16$ & $692.1 \pm 16.9$ & $296.6 \pm 14.1$ & $87.30 \pm 23.42$ \\
Dec 2004 & 10 & $204.7 \pm 9.56$ & $89.2 \pm 2.03$ & $70.9 \pm 2.85$ & $624.0 \pm 41.5$ & $297.2 \pm 14.8$ & $88.14 \pm 19.26$ \\
Jan 2005 & 7 & $189.4 \pm 13.9$ & $82.1 \pm 5.35$ & $66.8 \pm 4.16$ & $242.8 \pm 45.5$ & $121.4 \pm 22.8$ & $55.14 \pm 18.37$ \\
Feb 2005 & 10 & $169.7 \pm 10.6$ & $98.2 \pm 12.3$ & $70.1 \pm 3.47$ & $574.4 \pm 40.9$ & $255.4 \pm 22.2$ & $79.30 \pm 10.51$ \\
Mar 2005 & 7 & $167.1 \pm 11.5$ & $117.7 \pm 6.04$ & $109.1 \pm 3.67$ & $553.8 \pm 83.2$ & $305.3 \pm 53.3$ & $75.14 \pm 23.75$ \\
Apr 2005 & 10 & $115.5 \pm 8.81$ & $80.1 \pm 4.36$ & $71.6 \pm 5.18$ & $485.7 \pm 66.5$ & $323.7 \pm 57.7$ & $84.22 \pm 26.07$ \\
Maty 2005 & 6 & $84.2 \pm 2.59$ & $63.0 \pm 2.39$ & $51.2 \pm 2.57$ & $470.3 \pm 18.9$ & $230.5 \pm 12.6$ & $78.42 \pm 10.56$ \\
Oct 2005 & 9 & $124.1 \pm 8.47$ & $90.2 \pm 1.58$ & $69.5 \pm 2.01$ & $536.8 \pm 10.1$ & $272.3 \pm 19.3$ & $89.72 \pm 15.13$ \\
Overall & 77 & $147.7 \pm 13.5$ & $90.4 \pm 5.0$ & $72.8 \pm 5.1$ & $533.3 \pm 43.1$ & $264.5 \pm 20.1$ & $81.4 \pm 3.9$ \\
\hline
\end{tabular}

of low numbers, we could not test for differences in sex-ratios in different size classes. However, the male to female sex-ratio of clams $<150 \mathrm{~mm}$ was $2: 1$, and 1:1.2 in geoducks larger $>150 \mathrm{~mm}$ was. No evidence of hermaphroditism was detected during the study period.

\section{DISCLSSION}

The population of $P$. globosa sampled in this study was dominated by large individuals with an absence of small geoducks. Such population size structures have commonly been reported for both $P$. abrupta and $P$. zelanica (Goodwin \& Shaul 1984, Gribben \& Creese 2003). Recruitment in populations of $P$. abrupta and $P$. zelandica is highly variable both spatially and temporally (Goodwin \& Shaul 1984, Gribben \& Creese 2003), and it appears that. despite the sample size in this study not being particularly large ( $n=77$ geoducks in total), this may also be true for P. globosa. There is little evidence to suggest that resident recruitment in geoduck populations is density dependent (Orensanz et al. 2004). Although the method of sampling (i.e., the location of siphon holes) may have biased the size range of P. globosa collected (Goodwin \& Pease 1991). Gribben \& Creese (2003) found that $P$. zelandica as small as $45 \mathrm{~mm}$ could be readily found if present. If poor recruitment is a generally feature for populations of $P$. globosa then fisheries managers will have to carefully consider appropriate rates of harvesting.

Of the two other geoduck species for which significant morphological data is available, $P$. globosa is more similar in size to $P$. abrupta than $P$. zelandica. The mean shell length $(147.7 \mathrm{~mm})$ and maximum individual shell length $(239 \mathrm{~mm})$ recorded for $P$. globosa in this study were similar to the maximum shell lengths $(>200 \mathrm{~mm})$, and means (130-150 mm) recorded for populations of $P$. abrupta in British Columbia and Washington State (Harbo et al. 1983, Goodwin \& Pease 1991). The maximum length recorded length for $P$. zelandica is $146 \mathrm{~mm}$ with estimated population means of between $100-110 \mathrm{~mm}$ (Gribben \& Creese 2005). In terms of whole wet weight. $P$. globosa collected in this study appear smaller than P. abrupta but larger than $P$. zelandica. The heaviest geoduck in this study was $960 \mathrm{~g}$ whole wet weight with the overall mean ca. $530 \mathrm{~g}$. Individual whole wet weights of $>3 \mathrm{~kg}$ have been recorded for $P$. ahrupta with population means between 900 and $1.100 \mathrm{~g}$ commonly reported (Goodwin \& Pease 1991. Hand \& Dovey 1999). Maximum recorded individual whole wet weight for
$P$. zelandica is $620 \mathrm{~g}$ with population means between $242-359 \mathrm{~g}$ (Gribben 2003, Gribben et al. 2004).

Although there was a significant correlation between 9 out of the 15 morphometric comparisons. in most instances the coefficients of determination were low indicating reasonably higher variability between the variables measured. Factors influencing both shell measures, and the whole wet weight and wet tissue weight are likely to contribute to this variability. Firstly, the shape of geoduck shells is greatly affected by the sediments in which geoducks are located. Geoducks in peagravel or shell substrata often have misshapen shells (Goodwin \& Pease 1991). Moreover, substrate type can affect burial depth. which can lead to shorter siphons and potentially reduce tissue

TABI.E 2.

Morphometric relationships of geoduck clam (Panopea globosa), collected in Bahia de Guaymas-Empalme Mexico from October 2004 to October 2005. $r^{2}=$ determination coefficient; $\mathrm{a}=$ intercept; $\mathrm{b}=$ slope. $\boldsymbol{n}=77$.

\begin{tabular}{|c|c|c|c|c|c|}
\hline & $\begin{array}{l}\text { Shell } \\
\text { Length }\end{array}$ & $\begin{array}{l}\text { Shell } \\
\text { Width }\end{array}$ & $\begin{array}{l}\text { Shell } \\
\text { Mass }\end{array}$ & $\begin{array}{c}\text { Shell } \\
\text { Thickness }\end{array}$ & $\begin{array}{l}\text { Total } \\
\text { Mass }\end{array}$ \\
\hline \multicolumn{6}{|c|}{ Shell width } \\
\hline$r^{2}$ & $0.52 *$ & & & & \\
\hline a & 58.6 & & & & \\
\hline b & 0.1834 & & & & \\
\hline \multicolumn{6}{|c|}{ Shell mass } \\
\hline$r^{2}$ & $0.26^{*}$ & $0.41^{* *}$ & & & \\
\hline a & 57.72 & 67.33 & & & \\
\hline b & 0.1638 & 0.2305 & & & \\
\hline \multicolumn{6}{|c|}{ Shell thickness } \\
\hline$\dot{r}^{2}$ & 0.09 & 0.476 & 0.14 & & \\
\hline a & 55.29 & 8.70 & 55.17 & & \\
\hline b & 0.12 & 0.76 & 0.23 & & \\
\hline \multicolumn{6}{|c|}{ Total mass } \\
\hline$r^{2}$ & $0.3014^{*=}$ & $0.51=0$ & $0.81^{* *}$ & 0.182 & \\
\hline a & 355.11 & 29.034 & 15.851 & 52.57 & \\
\hline b & 1.2572 & 5.9763 & 0.1223 & 0.03 & \\
\hline \multicolumn{6}{|c|}{ Tissue wet mass } \\
\hline$r^{2}$ & 0.13 & $0.45^{* *}$ & $0.73^{* \bullet}$ & 0.212 & $0.81^{=*}$ \\
\hline a & 224.13 & 40.155 & 70.861 & 50.83 & 49.219 \\
\hline b & 0.2562 & 2.5788 & 2.3262 & 0.089 & 0.3919 \\
\hline
\end{tabular}

* Significance $(P<0.05)$ : ** $(P<0.001): n=77$. 

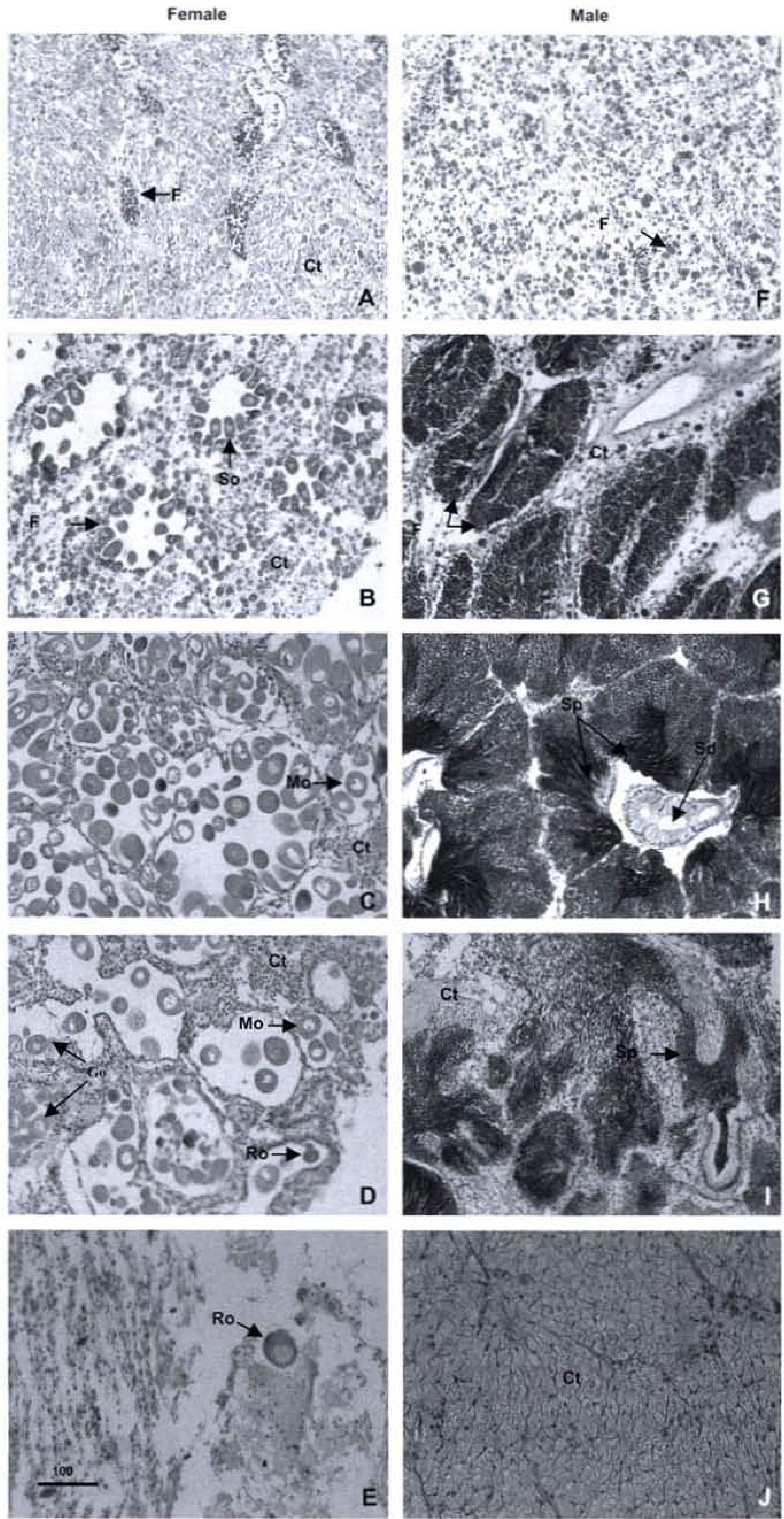

Figure 4. Histological sections of the reproductive stages of females and males gonads of Panopea glohosa: early active (A. F), late active (B, G), ripe (C. H), partially spawned (D, I), spent (E), and undifferentiated (J). Fo, follicle; Ct, connective tissue: So, secondary oocyte: Mo, mature oocyte; Ro. reabsorbing oocyte: and Sp, spermatozoids; Sd, Sperm duct. Scale bar $=100 \mu$. 

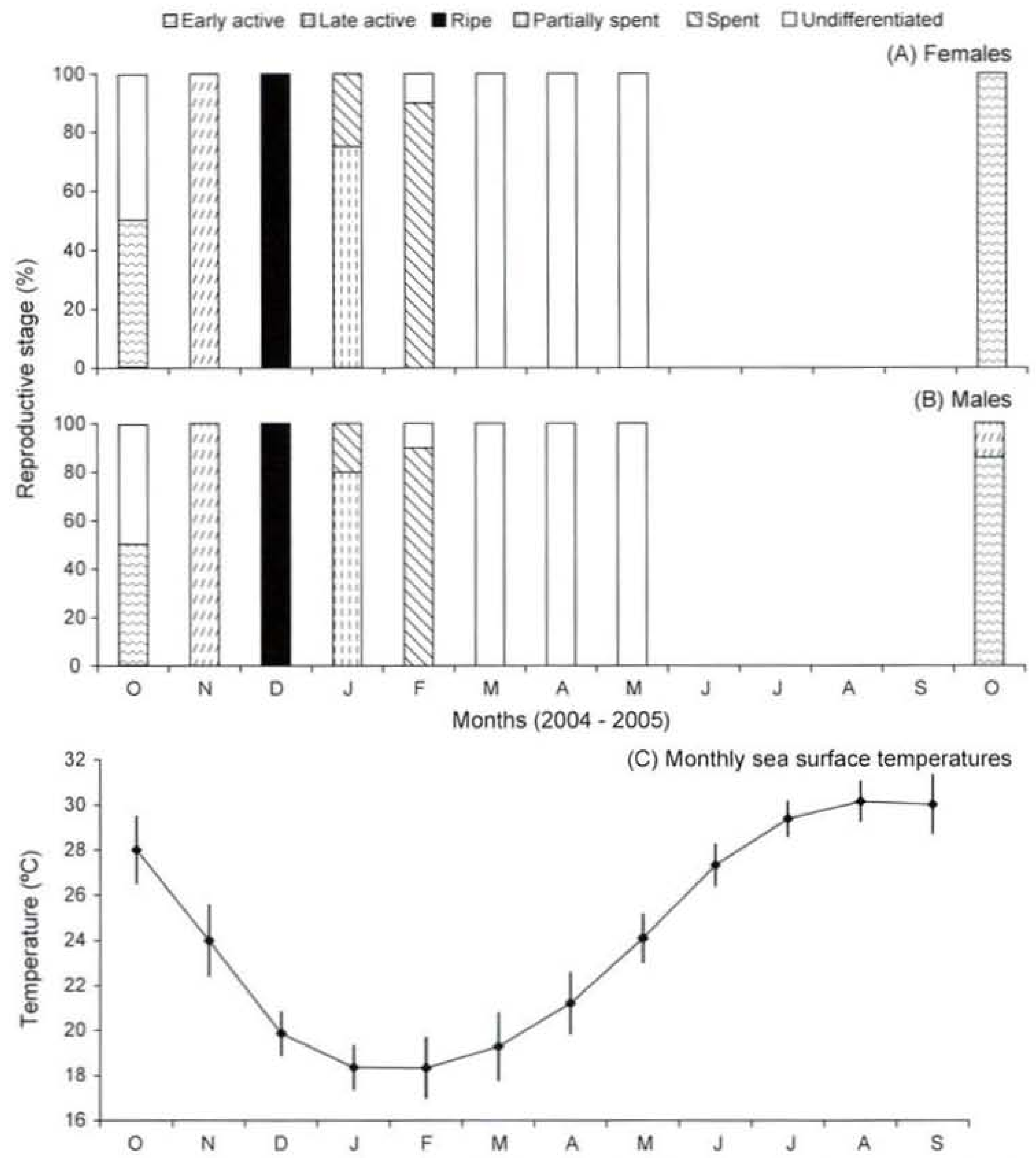

Figure 5. Reproductive cycle of Panopea globosa in the east central Gulf of California: (A) female, (B) male, and (C) monthly mean sea surface temperature.

in shallow buried geoducks. We did not collect information on sediment type, however, within beds geoducks occur across a wide range of substrata (from large stones of sand-silt sediments) (Gribben et al. 2004). Collection of geoducks from heterogeneous substrata is likely to increase variability between shell traits and potentially tissue weights. Secondly, the use of wet weights, which also include water contained in the mantle cavity and in within tissues themselves, may have also increased variability within traits. Differential retention of water in the mantle cavity or within tissues by individuals may have contributed to variability in whole wet weight, and wet tissue weight. However, Gribben \& Creese (2003) found a strong correlation between whole wet weight and whole drained wet weight (i.e., removal of water from the mantle cavity) for two populations of $P$. zelandica $\left(r^{2}=0.79\right.$ and 0.92$)$.

The reproductive stages described by Campbell and Ming (2003) for P. abrupta and by Gribben et al. (2004) correlated well with the reproductive stages observed in $P$. globosa in this study. Reproductive development and spawning of P. globosa from Bahia de Guaymas-Empalme was synchronous between the sexes. Similar patterns have also been reported for the Pacific geoduck. Panopea abrupta, and the New Zealand geoduck. Panopea zelandica (Andersen 1971. Gribben et al. 2004), although, slight differences in the timing of gametogenic development and spawning for populations of P. abrupta have also been reported (Goodwin 1976, Sloan \& Robinson 1984).

Gametogenic development for both P. abrupta and $P$. zelandica starts during late/autumn winter when water temperatures are low with continued development and spawning occurring through spring and summer as water temperatures rise. The reverse pattern was observed in this study for $P$. globosa with gametogenic development commencing in late summer when water temperatures were high $\left(\sim 28^{\circ} \mathrm{C}\right)$ and continued development and spawning occurring through winter as water temperatures fell. However, these patterns are consistent with the patterns of reproductive development and spawning described for other infaunal bivalve species found in the Gulf of California (e.g., Villalejo-Fuerte et al. 1996 and references therein). Winter spawning of bivalves in this region correlates with seasonally high larval food availability (Villalejo-Fuerte et al. 1996). 


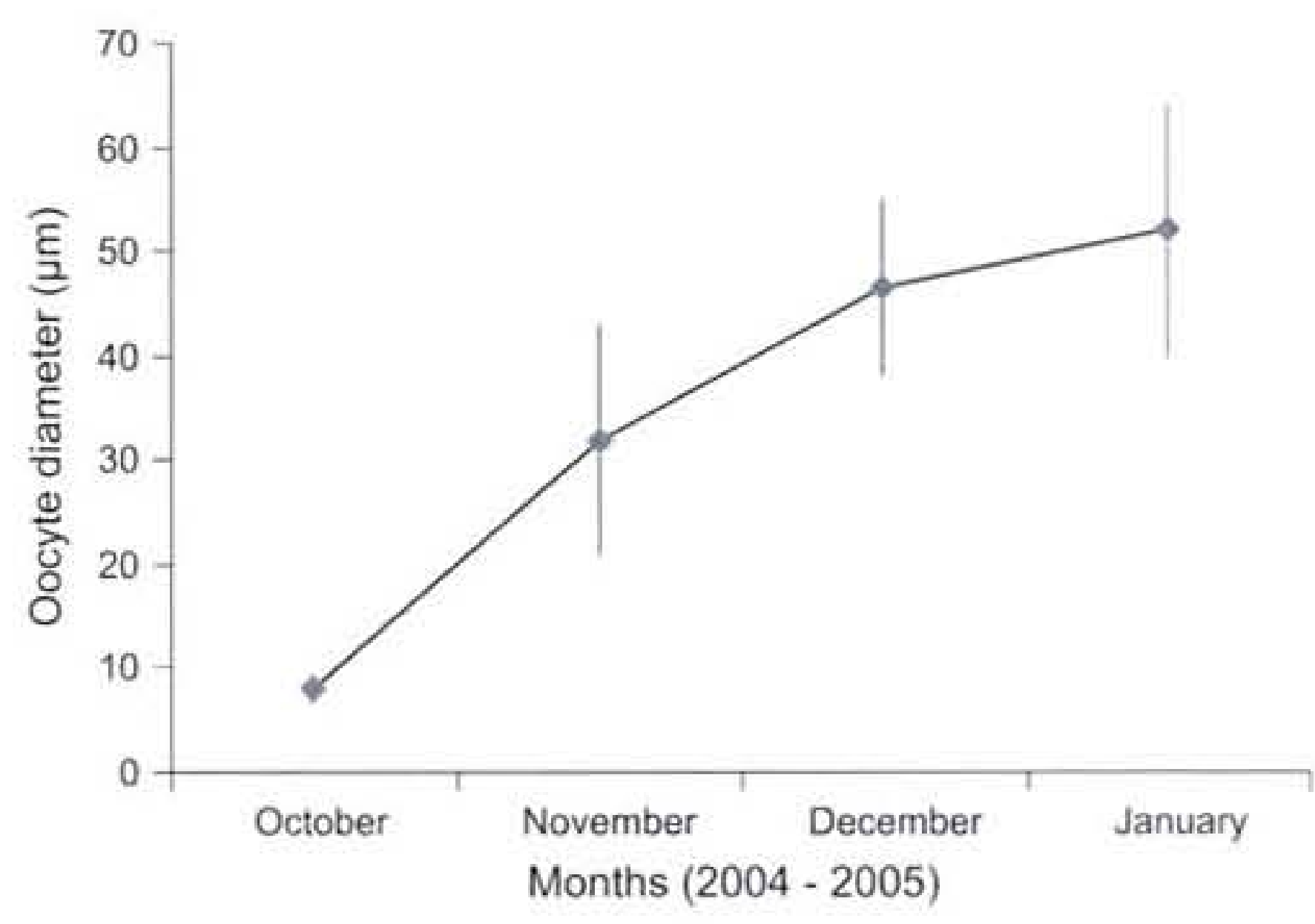

Figure 6. Average monthly oocyte diameters ( $=$ SE) of Panopea globosa in the east central Gulf of California.

Compared with other geoduck species. $P$. globosa, appears to have a short reproductive cycle and an extended resting period during which clams could not be sexed (possibly up to 7 mo). Gribben et al. (2004) found that $P$. zelandica had a resting phase of only I- 2 mo during which time clams could sexed. The
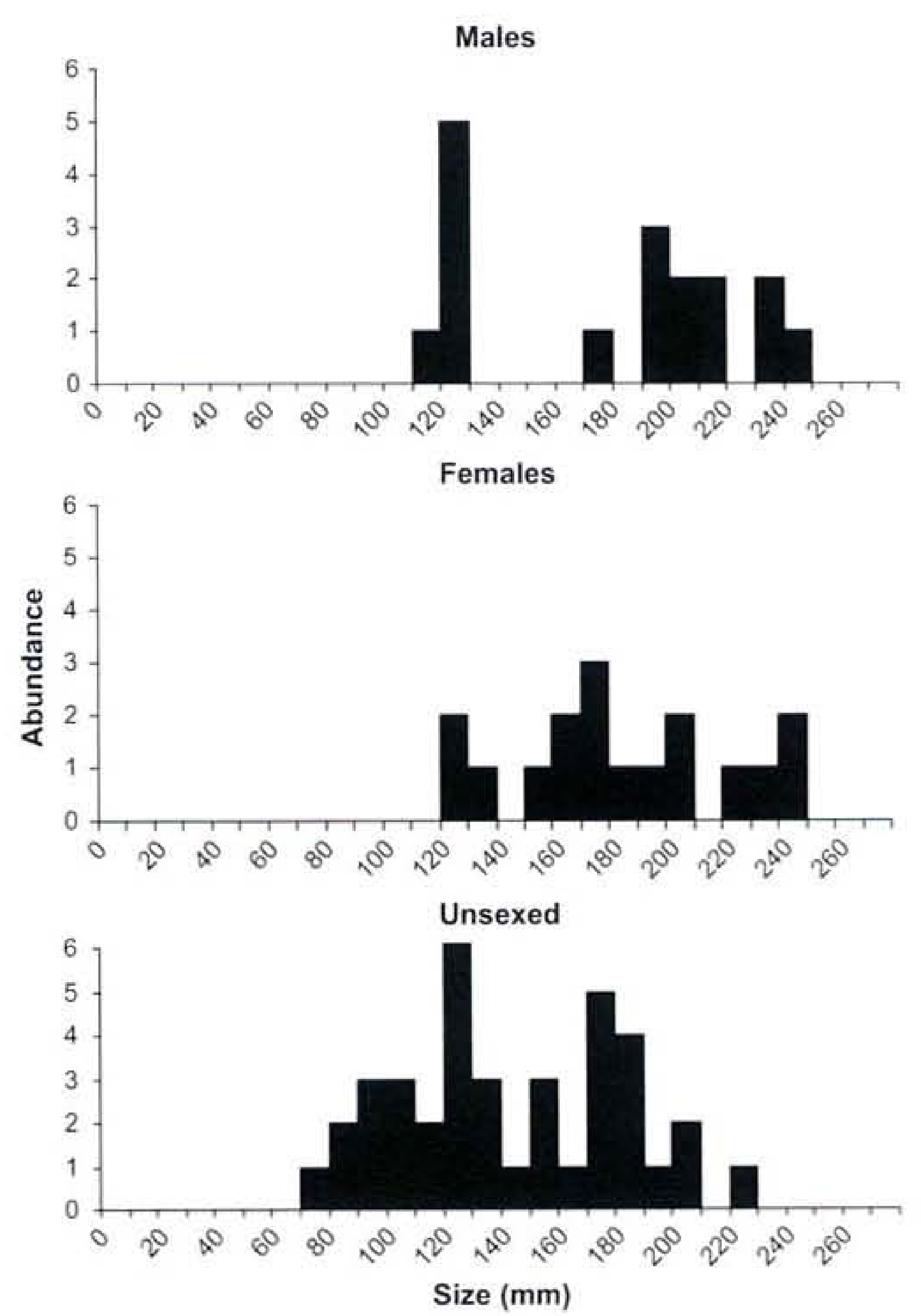

Figure 7. Shell length frequency distributions of individual male, female, and unsexed geoducks. reproductive cycle of $P$. abrupta from populations in Washington State and British Columbia has been shown to be continuous with no resting period occurring (Andersen 1971, Sloan and Robinson 1984). Villalejo-Fuerte et al. (1996) suggested that high water temperatures in the Gulf of California inhibit gametogenesis of infaunal bivalves from this region.

Mean monthly oocyte diameter was a good quantitative descriptor of reproductive development and spawning in P. zelandica (Gribben et al. 2004). A close relationship between monthly mean oocyte diameter and the gametogenic cycle was also found in Laevicardium elatum in Baja California (VillalejoFuerte et al. 1996), and Spisula solidissima similis in St Catherines Sound, GA (Kanti et al. 1993). In this study. monthly mean oocyte diameters of $P$. glohosa increased with gametogenic development. Given the apparent short reproductive season of $P$, globosa. monthly mean oocyte diameters appear to be a good descriptor of reproductive development of females.

Oocyte diameters for $P$. globosa in this study ranged from 6 $64 \mu \mathrm{m}$. A similar size range $(5-78 \mu \mathrm{m})$ was reported by Gribben et al. (2004) for $P$. zelandica. Gribben et al. (2004) also report similar mean monthly oocyte diameters through the different stages of reproductive development. They found that small primary oocytes had an average size between 10.3 and $13 \mu \mathrm{m}$ in two different populations and these cells dominated during the early winter (June and July). Here, we found an average size of $8 \pm 1.3 \mu \mathrm{m}$ during early autumn (October). The median size of $P$. zelandica oocytes in August and September (late winter in southern hemisphere). when increasing gametogenic activity occurred. was $40.3 \mu \mathrm{m}$. We observed an average size of $38 \pm 12 \mu \mathrm{m}$ for November and December (early winter). Finally, in $P$. zelandica, the largest monthly mean oocyte diameters occurred in the months immediately after the beginning of spawning in summer (January and February). Similar results were obtained in this study with the highest oocyte diameters (52 $\mu \mathrm{m})$ found after spawning in winter (January and February) (Fig. 6).

Although overall male to female sex-ratio of $P$. globosa in this study was $I: I$, there were more males than females $<150 \mathrm{~mm}$ and more with females than males $>150 \mathrm{~mm}$. The small sample size and absence of small individuals means we can say little about the sexual development and size at maturity for $P$. globosa. However. given that functional protandric dioecy has been shown to occur in $P$, zelandica and may also occur in P. abrupta (Gribben \& Creese 2003. Vadopalas et al. 2006) then future studies need to address the sexual development of this species, because the presence of protandry has potential ramifications for the sustainability of harvested populations (see discussion in Gribben \& Creese 2003).

In summary, this study represents the first detailed ecological study of P. globosa. Given the eminent development of fisheries and interest in developing aquaculture for this species, this study is timely and forms the basis for future research. However, to obtain a more accurate representation of the size structure of the population a larger number of samples will need to be collected. To develop sustainable fisheries for this species, future research needs to address issues such as recruitment and sexual development and to investigate differences in population estimates and life-history traits between populations of P. globosa. 


\section{ACKNOWLEDGMENTS}

This study was supported by CIBNOR Project 925-I and from the regular budget of the Instituto Nacional de la Pesca in
Guaymas. Sonora. Mexico. The SCUBA diving team of the "Ricardo Loreto" fisheries cooperative assisted in field sampling. The manuscript greatly benefited from the comments of two anonymous referees.

\section{LITERATURE CITED}

Andersen, A. M. 1971. Spawning, growth, and spatial distribution of the geoduck clam. Panope abrupta Gould. in Hood Canal, Washington. Unpubl. PhD. Thesis, University of Washington, USA

Arambula-Pujol. E. M. 2006. Ciclo reproductivo de la almeja de sifón Pamopea globosa en la Playa del Sol, Empalme, Sonora. México. Master's Thesis. Centro de Investigaciones Biológicas del Noroeste. La Paz. B.C.S.. Mexico, 56 pp.

Baron. J. 1992. Reproductive cycles of the bivalve molluses Atactodea striata (Gmelin), Gafrarium tumidum Roding and Anadara scapha (L.) in New Caledonia. Aust. J. Mar. Freshwater Res, 43:393-402.

Breen, P.. A. C. Gabriel \& T. Tyson. 1991. Preliminary estimates of age. mortality, growth. and reproduction in the hiatellid clam Panopea zelandica in New Zealand. N. Z. J. Mar. Freshwater Res. 25:231-237.

Breen, P. A. 1994. Sustainable fishing patterns for the geoduck clam (Panopea zelandica) populations in New Zealand. N.Z. Fish. Assess. Res. Doc, $944.21 \mathrm{pp}$

Campbell. A. \& M. D. Ming. 2003. Maturity and growth of the Pacific geoduck clam, Panopea abrupla, in Southern British Columbia. Canada. J. Shellfish Rex. 22:85-90.

Campbell. A., B. Clapp. C. M. Hand. R. Harbo, J. Hume \& G. Sharf. 1998. Survey of geoduck population density in Goletas Channel. Can. Tech. Rep. Fish. Aquat. Sci. 2214:319-343.

Cerrato, R. M. \& D. L. Keith. 1992. Age structure, growth, and morphometric variations in the Atlantic surf clam, Spisula solidissima, from estuarine and inshore waters. Mar. Biol. 114:581-593.

Eager, R. M.. N. M. Stone \& P. A. Dickson. 1984. Correlations between shape, weight and thickness of shell in four populations of Venerupis rhomhoids (Pennant). >. Moll. Stud. 50:19-38.

Goodwin. C. L. 1976. Observations on spawning and growth of subtidal geoduck (Panope generosa. Gould). Proc. Natl. Shellfish. Ass. 65:49-58.

Goodwin. C. L. \& B. Pease. 1989. Species Profiles: life histories and environmental requirements of coastal fish and invertebrates (Pacific Northwest) - Pacific geoduck clam. U.S. Wild Fish. Serv. Biol. Rep. 82 (11.120). U.S. Army Corps of Engineers. TR EL-82-4. 15 pp.

Goodwin. C. L. \& B. Pease. 1991. Geoduck. Panopea ahrupta (Conrad. 1849), size, density. and quality as related to various environmental parameters in Puget Sound, Washington. J. Shellfish Res. 10:65-77.

Goodwin. C. L. \& W. Shaul. 1984. Age, recruitment and growth of the geoduck clam (Panope generosa, Gould) in Puget Sound. Washington. Wash. Dept. Fish. Tech. Rep. 215, 29.

Gribben. P. E. 2003. Demography and life history characteristics of the New Zealand geoduck, Panopea zelandica. Ph.D Thesis, University of Auckland. $182 \mathrm{pp}$.

Gribben. P. E. \& R. G. Creese. 2003. Protandry in the New Zealand geoduck, Panopea zelandica (Mollusca, Bivalvia), Invertebr. Reprod. Der. 44:119-129.

Gribben. P. E. \& R. G. Creese. 2005. Age, growth, and mortality of the New Zealand geoduck clam, Panopea zelandica (Bivalvia: Hiattellidae) in two North Island populations, Bull. Mar. Sci, 77:119-135.

Gribben, P. E.. J. Helson \& A. G. Jeffs. 2004. Reproductive cycle of the New Zealand geoduck. Panopea zelandica, in two north island populations. Veliger 47:53-65.

Gribben. P. E., J. Helson \& R. Millar. 2004. Population abundance estimates of the New Zealand geoduck clam. Panopea zelandica. using North American methodology: Is the technology transferable? J. Shellfish Res. 23:683 69I.
Hand, C. M. \& G. Dovey. 1999. A survey of geoduck populations in the Elbow Bank and Yellow Bank area of Clayoquat Sound. West Vancouver Island, in 1994 and 1995. Can. Manuser. Rep. Fish. Aquat. Sci. 2479.33 pp.

Harbo, R. 1998. New directions in invertebrate fisheries management in British Columbia, Canada. Can, Spec. Publ. Fish. Aquat. Sci. 125:429-437.

Harbo, R., B. E. Adkins. P. A. Breen \& K. L. Hobbs, 1983. Age and size in market samples of geoduc clams (Panope generosa). Can. Manuscr. Rep. Fish. Aquat. Sci. 1714.78 pp.

Hendrickx. M. E.. R. C. Brusca \& L. T. Findley, 2005. A distributional checklist of the macrofauna of the Gulf of California. Mexico. Part I. Invertebrates. Arizona-Sonora Desert Museum. 429 pp.

Hoffman, A.. A. Bradbury \& C. L. Goodwin. 2000. Modeling geoduck. Panopea abrupta (Conrad 1849) population dynamics. 1. Growth. J. Shellfish Res. 19:57-62.

Kanti. A., P. B. Heffernan \& R. L. Walker. 1993. Gametogenic cycle of the southern surfelam. Spisula solidissima simtilis (Say. 1822), from St. Catherines Sound. Georgia. J. Shellfish Res. 12: $255-261$.

Keen. A. M. 1971. Sea shells of tropical west America. Marine mollusks from Baja California to Peru. Stanford University Press. Second Ed. Stanford, CA. 1064 pp.

Maldonado-Amparo. R. \& A. M. Ibarra. 2002a. Ultrastructural characteristic of spermatogenesis in diploid and triploid catarinat scallop (Argopecten ventricosus Sowerby II, 1842). J. Shellfish Res, 21:93-101.

Maldonado-Amparo, R. \& A. M. Ibarra, 2002b. Comparative analysis of oocyte type frequencies in diploid and triploid catarina scallop (Argopecten ventricosus) as indicators of meiotic failure. J. Shellfish Res. 21:597-603.

Newell. N. D.\& H. Hidu. 1982. The effects of sediment type on growth rate and shell allometry in the soft shelled clam, Mya arenaria $\mathrm{L}$. . Exp. Mar. Biol. Ecol. 65:285-295.

Orensanz, J. M.. C. M. Hand. A. M. Parma, J. Valero \& R. Hilborn. 2004. Precaution in the harvest of Methuselah's clams - the difficulty of getting timely feedback from slow-paced dynamics? Can. $J$. Fish. Aquat. Sci. 61:1355-1372.

Reynolds, R. W.. N. A. Rayner. T. M. Smith. D. C. Stokes \& W. Wang. 2002. An improved in situ and satellite SST analysis for climate. J. Climate 16:1609-1625.

Rodriguez-Jaramillo. C.. A. N. Maeda-Martinez, M. E. Valdez. T. Reynoso-Granados, P. Monsalvo-Spencer. D. Prado-Ancona, F. Cardoza-Velasco. M. Robles-Mungaray \& M. T. Sicard. 2001. The effect of temperature on the reproductive maturity of the penshell Atrina maara (Sowerby. 1835) (Bivalvia:Pinnidae). J. Shellfish Res. 20:39-47.

Sloan, N. A. \& S. M. C. Robinson. 1984. Age and gonad development in the geoduck clam Panope ahrupta (Conrad) from southern British Columbia. Canada. J. Shellfish Res. 4:131-137.

Vadopalas, B., C. S. Y. Ma. J. P. Davis \& C. S. Friedman. 2006. Protandry, maturation, and spawning in cultured intertidal geoduck (Panopea ahrupta) clams. J. Shellfish Res. 25:784.

Villalejo-Fuerte, M.. B. P. Ceballos-Vảzqueı \& F. Garcia-Dominguez. 1996. Reproductive cycle of Laevicardium clatum (Sowerby, 1833) (Bivalvia: Cardiidae) in Bahia Concepcion. Baja California Sur. Mexico, I, Shellfish Res. 15:741-745. 